\title{
A glance into the beauty of Fixed Point Theory: Professor Emeritus Ioan A. Rus on his 80th anniversary
}

\section{VASILE BERINDE ${ }^{1,2}$ and MĂDĂLINA PĂCURAR ${ }^{3}$}

\begin{abstract}
.
Professor Emeritus Ioan A. Rus, a prominent and unfatiguable mathematician with an impressive oeuvre in the field of Nonlinear Analysis, particularly in Fixed Point Theory, will be 80 on 28th of August 2016. On this occasion, we would like to congratulate him and wish him good health, happiness, the same impressive physical and mental vigour, as well as new bright results in mathematics.

We also take this opportunity to present some information on the visibility and impact of Professor Rus' main scientific contributions, which would thus complement the information given in the following anniversary articles [Berinde, V. and Petruşel, A., Professor Ioan A. Rus on his 70th birthday: a complete scientist, an accomplished mathematician, Fixed Point Theory 7 (2006), No. 2, 167-174; Berinde, V. and Păcurar, M., The joy of doing mathematics. Interview with Professor Ioan A. Rus, Eur. Math. Soc. Newsl., 76 (2010), 47-50; Petruşel, A., Professor Ioan A. Rus on his 75th birthday, Fixed point theory and its applications, 33-38, Casa Cătţii de Ştiinţă, Cluj-Napoca, 2013].
\end{abstract}

Acknowledgements. The first author's work on this paper has been done during his visit to the Department of Mathematics and Statistics, King Fahd University of Petroleum and Minerals, Dhahran, Saudi Arabia (April-May 2016). He gratefully thanks Dr. AlHomidan, dean of College of Sciences, and Dr. Al-Attas, the Chairman of the Department of Mathematics and Statistics, for the excellent facilities they offered during the visit. The first author would also like to acknowledge the support provided by the Deanship of Scientific Research at King Fahd University of Petroleum and Minerals for funding this work through the projects IN151014 and IN151017. The research was also supported by the CNCS-UEFISCDI project number PN-II-ID-PCE-2011-3-0087, ctr. No. 315.

\section{REFERENCES}

[1] Berinde, V. and Petruşel, A., Professor Ioan A. Rus on his 70th birthday: a complete scientist, an accomplished mathematician, Fixed Point Theory, 7 (2006), No. 2, 167-174

[2] Berinde, V. and Păcurar, M., The joy of doing mathematics. Interview with Professor Ioan A. Rus, Eur. Math. Soc. Newsl., 76 (2010), 47-50

[3] Petruşel, A., Professor Ioan A. Rus on his 75th birthday, Fixed point theory and its applications, 33-38, Casa Cărţii de Ştiinţă, Cluj-Napoca, 2013

[4] Szilágyi, P., Professor Ioan A. Rus at his 60th anniversary, Studia Univ. Babeş-Bolyai Math., 41 (1996), No. 4, $1-9$

${ }^{1}$ Department of MATHematics ANd COMPUter SCience

NORTH UNIVERSITY OF BAIA MARE

Victoriei 76, 430122 BAIA MARE, ROMANIA

E-mail address: vberinde@ubm.ro

Received: 15.03.2016; In revised form: 23.03.2016; Accepted: 23.03.2016

Key words and phrases. anniversary. 
2 Department of Mathematics and Statistics

King Fahd University of Petroleum and Minerals

DHAHRAM, KINGDOM OF SAUdi ARABIA

E-mail address: vasile.berinde@gmail.com

${ }^{3}$ Department of Statistics Forecast and Mathematics Faculty of Economics AND BuSSINESS ADMINISTRATION BABEŞ-BOLYAi UNIVERSITY OF ClUJ-NAPOCA

56-60 T. Mihali St., 400591 Cluj-NAPOCa Romania

E-mail address: madalina.pacurar@econ.ubbcluj.ro 